\title{
LAWFARE E PROCESSO PENAL DEMOCRÁTICO: A CONSTRUÇÃO PARTICIPADA E RACIONAL DO MÉRITO PROCESSUAL
}

\author{
LAWFARE AND DEMOCRATIC PENAL PROCESS: THE PARTICIPATED AND RATIONAL \\ CONSTRUCTION OF PROCEDURAL MERIT
}

\section{Fabricio Veiga Costa}

Pós-doutorado em educação pela UFMG. Doutorado em direito processual pela PUCMINAS (2012). Mestrado em direito processual pela PUCMINAS (2006). Especialista em direito processual (2003), Direito de família (2009) e Direito educacional (2014). Professor do mestrado em direitos fundamentais da Universidade de Itaúna. Bacharel em direito pela Universidade Federal de Uberlândia (2002).

E-mail: fvcufu@uol.com.br

\begin{abstract}
Alisson Thiago de Assis Campos
Doutorando em Direito pela Universidade de Itaúna - UIT (2020-2023). Mestre em Proteção dos Direitos Fundamentais, dentro da linha de pesquisa de Organizações Internacionais e a Proteção dos Direitos Fundamentais da Universidade de Itaúna - UIT (2017-2018). Pós-graduado em Ciências Penais (2013). Graduado em Direito pela Faculdade de Direito de Conselheiro Lafaiete - FDCL (2007-2011). Atualmente atua como Professor e DiretorAcadêmico na Faculdade de Direito de Conselheiro Lafaiete - FDCL. E-mail: alissonateticano@gmail.com
\end{abstract}

Recebido em: 29/08/2020

Aprovado em: 18/01/2021

RESUMO: O objetivo da presente pesquisa é compreender os fundamentos teóricos do instituto do lawfare, de modo a demonstrar sua incompatibilidade com o processo penal democrático brasileiro. Etimologicamente lawfare advém das expressões "lei" e "guerra", tendo sido cunhada especialmente pelo direito norte-americano após o atentado de 11 de setembro de 2001. A partir de então, a lei passou a ser vista como um instrumento para uma guerra simbólica e silenciosa, ou seja, utiliza-se da lei para punir autocraticamente os sujeitos considerados inimigos do Estado (terroristas). O referido instituto tem sido veladamente aplicado no direito brasileiro, por meio de uma jurisprudência defensiva que prioriza um modelo autocrático de processo penal inquisitivo, que prestigia a punição dos ditos "inimigos do Estado e da sociedade civil" (políticos envolvidos em escândalos de corrupção; pedófilos, chefes de organizações criminosas, por exemplo). Por meio de uma pesquisa bibliográfica, documental, análises temáticas, teóricas, interpretativas e críticas, demonstrou-se que o lawfare contraria o modelo constitucional de processo penal democrático, tendo em vista que torna inviável a formação participada do mérito processual, cerceia o direito de defesa do acusado, além de enaltecer o protagonismo e a discricionariedade judicial.

Palavras-chave: Lawfare. Mérito processual participado. Processo penal democrático.

ABSTRACT: The aim of this research is to understand the theoretical foundations of the lawfare institute, in order to demonstrate its incompatibility as the Brazilian democratic criminal process. 
Etymologically lawfare comes from the expressions "law" and "war", having been coined especially by American law after the attack of September 11, 2001. From then the law came to be seen as an instrument for a symbolic war and silent, that is, it uses the law to punish autocratically subjects considered enemies of the state (terrorists). The aforementioned institute has been vehemently applied in Brazilian law, through a defensive jurisprudence that prioritizes an autocratic model of inquisitive criminal procedure, which prescribes the punishment of the socalled "enemies of the State and of civil society" (politicians involved in corruption scandals; pedophiles, heads of criminal organizations, for example). Through a bibliographical, documentary, thematic, theoretical, interpretative and critical analysis, it has been demonstrated that lawfare contradicts the constitutional model of democratic criminal procedure, since it makes it impossible to participate in procedural merit, defense of the accused, besides enhancing the protagonism and judicial discretion.

Keywords: Lawfare. Merit Process. Democratic criminal procedure.

SUMÁRIO: Introdução; 1. Compreensão, dimensão teórica e significação do termo Lawfare; 2. A processualidade penal constitucional como corolário para a legitimação das decisões judiciais no Estado Democrático de Direito; 3. O Lawfare como instrumento de perseguição e a ofensa ao processo penal constitucional; 4. Modelo de processo constitucional e a formação participada do mérito processual como meio de democratizar a construção do provimento final mediante a participação dialógica das partes interessadas; Conclusão; Referências.

\section{INTRODUÇÃO}

O objetivo da presente pesquisa é investigar o instituto do lawfare, compreender suas bases teóricas, analisar sua aplicabilidade no direito brasileiro para, assim, problematizar o debate da lei, vista como instrumento de guerra (não bélica) de eliminação dos inimigos do Estado, constituindo-se no instrumento de reprodução de um modelo autocrático de processo contrário ao garantismo penal, já que torna inviável a formação dialógico-democrática do provimento final pelos interessados, e constitui claro meio de cerceamento do direito de defesa das partes.

A escolha do tema se justifica em razão de sua relevância teórica e prática, especialmente no que atine à importância de investigar e demonstrar que o modelo de processo adotado, quando se aplica o lawfare, é autocrático, não condiz com as diretrizes democráticas que privilegiam a proteção jurídica integral da pessoa humana, que deve assegurar o contraditório, ampla defesa e devido processo legal. $\mathrm{O}$ direito de construção participada do mérito processual constitui requisito do provimento final democrático, pois, dessa forma, relativiza-se o protagonismo judicial e afasta a aplicabilidade de argumentos metajurídicos (axiológicos) como critério de punição e julgamento autocráticos dos inimigos do Estado.

A compreensão da dimensão teórica e a significação do termo lawfare, bem como os fundamentos utilizados para o seu entendimento no direito estrangeiro, foi de relevante importância para demonstrar sua gênese e o contex to histórico em que surgiu o referido instituto. O estudo da aplicabilidade de determinado instituto no direito interno exige de seus intérpretes e pesquisadores a compreensão dos seus fundamentos basilares, especialmente a análise do momento e cenário sociocultural e histórico em que foi sistematizado o lawfare.

Objetivando-se recortar a abordagem do tema lawfare com proposta de pesquisa apresentada, desenvolveu-se um estudo da constitucionalização do processo penal, especialmente na análise do garantismo penal, com o condão de demonstrar que o instituto em tela representa um meio institucionalizado de cercear o direito de defesa de acusados, limitando o contraditório e ampla defesa, além de submetê-los a penas autocráticas e desumanas, tudo em razão de tais acusados serem considerados inimigos do Estado. 
O direito de os interessados na lide participar da construção do mérito processual constitui um meio de relativizar o protagonismo judicial e, assim, democratizar a formação do provimento final. A partir da respectiva premissa desenvolveu-se um estudo sistemático do modelo constitucional do processo, com o condão de estabelecer um contraponto com o instituto do lawfare para, assim, demonstrar seu caráter autocrático e contrário os princípios constitucionais do processo. Pretendeu-se evidenciar a incompatibilidade jurídica do lawfare com o Estado Democrático de Direito, especialmente no que tange aos direitos do acusado, visto aprioristicamente como um inimigo do Estado e, por isso, normalmente tem cerceado seu direito de defesa.

Embora possua acepções distintas, o termo lawfare se refere ao uso da legislação e do aparato judicial como instrumentos de perseguição política e ideológica. A temática vem sendo amplamente discutida pela literatura jurídica mundial, posto que a prática de lawfare parece ser implementada em larga escala ao redor do mundo, inclusive no Brasil ${ }^{1}$, o que recomenda um estudo teórico aprofundado acerca do assunto. Objetiva-se investigar se o instituto do lawfare é compatível com os direitos fundamentais processuais dos jurisdicionados e, em seguida, realizar um estudo comparativo com o processo penal democrático brasileiro.

O marco teórico utilizado para a elaboração do artigo serão as obras de Fabrício Veiga Costa, Lênio Luiz Streck, Luigi Ferrajoli e Charles J. Dunlap, por meio de estudos realizados em artigos científicos e obras voltadas à compreensão da processualidade penal democrática em contraponto ao lawfare, sendo este último visto como perseguição política exercida através de instrumentos legais e mecanismos judiciais - notadamente processos que desrespeitam os princípios democráticos. Buscar-se-á entender o real significado da expressão lawfare e, para tanto, será necessária a realização de um recorte histórico acerca da utilização do termo ao longo dos anos. Diante das diversas manifestações do termo lawfare, o recorte epistemológico aqui trabalhado está ligado exclusivamente à implementação de técnicas judiciais e legislativas utilizadas para fins de opressão de determinadas classes (ou indivíduos).

Após essa conceituação inicial, os princípios constitucionais que norteiam o processo no Brasil serão abordados e analisados como instrumentos de legitimação das decisões judiciais, a fim de demonstrar que somente os procedimentos que respeitam a Constituição Federal encontram legitimidade na sistemática jurídica brasileira. Por fim, a prática de lawfare será apontada como mecanismo de perseguição ilegítima, posto que ofende os princípios supramencionados.

A pergunta problema que delimita o objeto da pesquisa é a seguinte: a aplicabilidade do instituto do lawfare no direito brasileiro constitui uma afronta ao modelo constitucional e garantista de processo penal e compromete a formação participada do mérito processual? A hipótese científica proposta funda-se na problematização do estudo do instituto do lawfare frente ao processo penal brasileiro vigente, debatendo-se sistematicamente se o Estado poderá adotar posturas no sentido de eleger inimigos e se utilizar da lei como instrumento de punição autocrática de tais sujeitos.

Por meio de uma pesquisa bibliográfica e documental, construída a partir da realização de análises temáticas, teóricas, interpretativas e comparativas pretende-se analisar se a adoção do instituto do lawfare no direito brasileiro evidencia a intenção do Estado se utilizar autocraticamente do processo como espaço de punição de seus inimigos, utilizando-se da lei e de critérios axiológicos de interpretação como afronta à dignidade humana desses sujeitos. A utilização do método dedutivo

\footnotetext{
${ }^{1}$ A Portaria no 666, de 25 de julho de 2019, editada pelo Ministro da Justiça Sérgio Moro, dispõe sobre o impedimento de ingresso, a repatriação e a deportação sumária de pessoa perigosa ou que tenha praticado ato contrário aos princípios e objetivos dispostos na Constituição Federal. A referida portaria evidencia claramente a existência do instituto do Lawfare no direito brasileiro, tendo em vista classifica como inimigos do Estado sujeitos suspeitos de envolvimento em terrorismo, organizações criminosas, tráfico de drogas e armas, pornografia ou exploração sexual infanto-juvenil e torcida com histórico de violência em estádios de futebol. Tais sujeitos serão sumariamente deportados ou repatriados, sem qualquer oportunidade de defesa, haja vista que são categorizados como inimigos do Estado brasileiro (BRASIL, Portaria 666).
} 
foi essencial para recortar o objeto da pesquisa, pois partiu-se do estudo do modelo constitucional de processo penal garantista para, assim, analisar pontualmente se a aplicabilidade do instituto do lawfare constitui afronta a esse modelo de processo que rege as instituições democráticas.

\section{COMPREENSÃO, DIMENSÃO TEÓRICA E SIGNIFICAÇÃO DO TERMO LAWFARE}

O termo Lawfare, por diversas vezes, é utilizado em concepções distintas e contraditórias, podendo assumir diferentes acepções, dependendo do contexto em que é empregado. Por se tratar de fenômeno relativamente recente, cujo conceito ainda se encontra em construção, torna-se necessário fixar as bases teóricas sob as quais está circunscrita a temática tratada no presente trabalho. O esclarecimento científico sobre as proposições e os parâmetros teóricos do instituto em tela é de fundamental importância para viabilizar a análise do objeto proposto, qual seja, a investigação da relação existente entre Lawfare, processo penal democrático ${ }^{2}$, construção participada e racional do mérito processual. Ou seja, pretende-se esclarecer se a carga metajurídica (axiológica) que integra o instituto do Lawfare constitui ou não óbice à construção democráticoparticipada do mérito no âmbito do processo penal.

\subsection{Breves apontamentos históricos do termo Lawfare}

A primeira vez que a expressão Lawfare foi utilizada em um contexto significativo remonta ao ano de 1975, quando John Carlson e Neville Yeomans publicaram um ensaio denominado "Whither goeth the law - humanity or barbarity" . Na referida obra os autores apresentavam um histórico sobre a utilização das técnicas de mediação como forma consensual para resolução de conflitos (CARLSON, YEAOMANS, 1975).

Muito embora não tenha discorrido de maneira clara sobre a utilização do termo Lawfareo que acaba dificultando a análise acerca da perspectiva semântica implementada pelos autores-a obra mencionada fornece alguns indícios que permitem a identificação da real intenção que reveste a cunhagem da expressão ora analisada. Nesse sentido, o termo Lawfare seria resultado da fusão (siglonimização) entre as palavras "law" (lei) e "warfare" (guerra) (CARLSON, YEAOMANS, 1975).

No contexto em que foi empregada por Carlson e Yeaomans, a palavra se referia a uma espécie de refinamento de técnicas em que a lei seria utilizada em substituição ao combate bélico propriamente dito. Em outras palavras, a conclusão a que se pode chegar a partir da leitura do texto é que, sob a influência das ideias prevalentes nos anos 70, os autores pensaram no Lawfare como uma tática pacífica que "substituiria a guerra e o duelo passaria a ser com palavras ao invés de espadas" (CARLSON, YEAOMANS, 1975). Nesse contexto propositivo a expressão pode ser entendida, em sua literalidade, como a utilização da lei como ferramenta para fundamentar a resolução de conflitos de interesses (o duelo entre as partes seria fundado nas palavras e argumentos, e não mais por meio de espadas e da força).

Após um período em desuso, o termo volta a ser novamente utilizado em 1999, quando dois oficiais do Exército Popular de Libertação da China chamados Qiao Liang e Wang Xiangsui publicaram um livro de estratégia militar traduzido para o inglês como "Unrestricted Warfare"4.

\footnotetext{
${ }^{2}$ Importante esclarecer que o primeiro item do desenvolvimento da pesquisa destina-se a demonstrar a origem e os fundamentos teórico-conceituais do instituto do lawfare. O estudo e análise detalhada da relação existente entre lawfare e processo penal democrático serão realizados nos itens subsequentes.

3 O título do ensaio publicado pela primeira vez no livro "The Way Out - Radical Alternatives in Australia" e disponível em http://www.laceweb.org.au/whi.htm (última visita em 2 de abril de 2017) pode ser livremente traduzido como "Para onde vai a Lei - Humanidade ou Barbárie". No contexto em que foi publicado, sugeria a utilização da Lei como um instrumento de promoção da paz social que visaria a substituir os combates armados pela legislação.

4 A obra original chinesa foi traduzida para o inglês e encontra-se disponível digitalmente em https://www.oodaloop.com/documents/unrestricted.pdf (última visita em 2 de abril de 2017). Após a disponibilização Revista de Direito Brasileira | Florianópolis, SC | v. 27 | n. 10 | p.178-200 | Set./Dez. 2020
} 
Na obra os termos 'Law' e 'Warfare' aparecem novamente juntos (embora não aglutinados) em um sentido oposto àquele apresentado anteriormente por Carlson e Yeaomans (LIANG; XIANGSUI, 1999). Para os oficiais chineses a guerra estava rompendo as fronteiras dos campos de batalha e assumindo outras formas "não-militares", incluindo a "Law Warfare" (guerra através das leis), que incluía a elaboração de normas e celebração de tratados internacionais estratégicos do ponto de vista da geopolítica. Nessa perspectiva, a expressão se refere a um método, dentre muitos possíveis, de utilização de um combate não convencional capaz de permitir que um Estado pudesse derrotar seu oponente, independentemente do seu grau de desenvolvimento bélico, sem a necessidade de um confronto militar direto. Segundo o entendimento dos autores chineses,

[...] podemos apontar uma série de outros meios e métodos utilizados para combater uma guerra não militar, alguns dos quais já existem e alguns dos quais podem existir no futuro. Tais meios e métodos incluem a guerra psicológica (espalhando rumores para intimidar o inimigo e desanimá-lo); Guerra do Contrabando (lançando confusão no mercado e atacando a ordem econômica); Guerra de mídia (manipulando o que as pessoas veem e ouvem a fim de guiar a opinião pública); Guerra das drogas (obtendo lucros ilícitos e repentinos espalhando desastre em outros países); Guerra em rede (aventurando-se em segredo e ocultando sua identidade num tipo de guerra do qual é praticamente impossível de se proteger); Guerra Tecnológica (Criando monopólios e estabelecendo padrões independentemente); Guerra de fabricação (Apresentando uma aparência falsa de força diante dos olhos do inimigo); Guerra de Recursos (obtendo riquezas através de lojas de recursos); Guerra de ajuda económica (concedendo favores abertamente e inventando controlar determinadas questões em segredo); Guerra cultural (liderando principais tendências culturais para assimilar aqueles com pontos de vista diferentes); e guerra de leis internacionais (aproveitando oportunidades para estabelecer regulamentos), etc. Além disso, existem outros tipos de guerra não-militar que são muito numerosas para mencionar. (LIANG, XIANGSUI, 1999, p. 55-56, tradução livre)

Etimologicamente, e a partir das proposições ora apresentadas acima, Lawfare pode ser definido como "guerra a partir das leis". A lei é a ferramenta não convencional utilizada pelos Estados para derrotar seu inimigo, dispensando-se a forma clássica de guerrear, pois nesse contexto não é necessário um confronto bélico e militar direto. É esse o sentido trabalhado pelos chineses, quando abordaram o tema Lawfare em seus estudos e estratégias de guerra, uma vez que deixam evidente que as estratégias bélico-militares constituem apenas mais um meio de conduzir uma guerra. A lei é vista como mais um desses instrumentos e ferramentas ideologicamente construídos para atacar aqueles sujeitos considerados inimigos do Estado ou das instituições que conduzem as diretrizes do sistema vigente.

A partir de 2001, o termo Lawfare se popularizou definitivamente e começou a ser encarado em uma perspectiva muito mais ampla. Isto porque em novembro daquele ano, ou seja, apenas dois meses após os atentados terroristas de 11 de setembro, o Coronel Charles J. Dunlap Jr. (Oficial da Força Aérea dos Estados Unidos - USAF) publicou o artigo "Law and Military Interventions: Preserving Humanitarian Values in $21^{\text {st }}$ Conflicts" ${ }^{\prime 5}$, que tratava sobre a prática maléfica do Lawfare dentro de um contexto de segurança nacional (DUNLAP, 2001). Nesse momento histórico foram delineados contornos teóricos sobre o instituto do Lawfare, já que a lei

digital, a obra foi utilizada de maneira sensacionalista e um livro chegou a ser editado com o subtítulo "o plano chinês para destruir a América", trazendo uma foto do World Trade Center em chamas na capa.

${ }^{5} \mathrm{O}$ trabalho foi preparado para apresentação na Conferência sobre os Desafios Humanitários nas Intervenções Militares realizado em Washington no dia 20 de Novembro de 2001 e seu título pode ser traduzido como "Lei e Intervenções Militares: Preservando os valores humanitários nos conflitos do século XXI. 
passa a ser vista como uma ferramenta útil para derrotar aqueles sujeitos considerados inimigos do Estado.

O atentado terrorista de 11 de setembro de 2001, nos Estados Unidos da América, serviu de marco histórico para a ressignificação do Lawfare. O instituto passou a ser uma estratégia de guerra fora dos conceitos clássicos, bélicos e armamentista, motivo esse que torna relevante a problemática científica proposta ao debate. A lei passa a ser a ferramenta utilizada pelo Estado para derrotar e punir severamente aqueles sujeitos considerados lesivos, inimigos aos interesses da sociedade, que nesse contexto histórico mencionado são os terroristas. Importante ressaltar que a aplicabilidade da lei como instrumento para derrotar os inimigos do Estado nem sempre condiz com a observância dos princípios constitucionais do processo (contraditório, ampla defesa, devido processo legal), já que o propósito é eliminar esse inimigo mediante a aplicabilidade de uma norma jurídica que o exclua e o elimine do sistema, tornando inviável a participação da parte interessada na construção do provimento final. Na obra acima destacada o Lawfare apresenta-se como uma nova característica dos combates do século XXI, pois o uso da lei como arma de guerra se dá como forma de estabilizar a política de combate ao terrorismo implementada pelos Estados Unidos (DUNLAP, 2001, p. 2).

'Lawfare' descreve um método de guerra onde a lei é usada como um mecanismo para atingir um objetivo militar. Embora, à primeira vista, se pudesse supor que a lei resultaria em menos sofrimento na guerra (e às vezes resulta), na prática muitas vezes produz comportamentos que comprometem a proteção dos verdadeiramente inocentes. Há muitas dimensões para o termo 'lawfare', mas a mais frequentemente adotada pelos adversários norte-americanos é uma manipulação cínica do império da lei e dos valores humanitários que ele representa. Em vez de conquistar vitórias no campo de batalha, per se, os adversários tentam destruir a vontade de lutar, minando o apoio público que é indispensável quando democracias como os EUA conduzem intervenções militares. Uma das principais formas de conseguir esse fim é fazer com que pareça que os EUA estão travando uma guerra em violação à letra ou ao espírito das Leis de Conflito Armado. (DUNLAP, 2001, p. 4 - tradução livre)

A lei é utilizada como símbolo que legitima aprioristicamente o poder do Estado em punir de forma severa e autocrática aqueles por ele eleitos como seus inimigos. Essa guerra simbólica, com substratos centrados na legalidade estrita, oferece à coletividade um sentimento de proteção e segurança. Em contrapartida, o sujeito eleito como inimigo do Estado tem suas garantias de defesa limitadas (muitas vezes suprimidas), pois é considerado um desertor que atenta contra os interesses públicos. O discurso utilizado pelo Estado é que a lei é a ferramenta que concretiza a justiça e garante a segurança da coletividade e, por isso, pode ser utilizada para repelir sumária e autocraticamente todos aqueles sujeitos considerados inimigos dos interesses sociais, por gerar instabilidade coletiva. Nesse contexto propositivo, verifica-se a sistematização de um modelo autocrático na forma de se pensar e aplicar a ciência do Direito. Esse discurso ideológico explica os fundamentos da sistematização teórica do instituto do Lawfare, visto num primeiro momento como garantidor da justiça social, mas, quando compreendido sob o viés crítico, fica evidente seu caráter ditadorial, pois objetiva o fortalecimento do poder estatal a partir da aplicação literal e fria a lei. Trata-se de instituto autocrático, que não condiz com as proposições trazidas pelo modelo constitucional de processo penal garantista, uma vez que seu propósito é coisificar o sujeito eleito como inimigo do Estado, não lhe assegurando o direito de resistir ao julgamento ao qual se submete, não lhe assegurando efetivamente os princípios constitucionais do processo (contraditório, ampla defesa, devido processo legal), tampouco permitindo a formação participada do mérito processual sob o viés do garantismo penal. 
Posteriormente, mais precisamente no inverno de 2008, o mesmo Charles Dunlap voltou a escrever sobre Lawfare em um comentário no Jornal de Assuntos Internacionais da Universidade de Yale. No texto intitulado de "Lawfare Today: a perspective" $\mathrm{o}$ autor tentou esclarecer o uso do termo Lawfare, reconhecendo a amplitude de sua conceituação:

Lawfare é um conceito cada vez mais discutido em círculos governamentais, acadêmicos e de mídia. Lamentavelmente, essa discussão não está tão bem informada quanto poderia estar. [...] Embora eu tenha brincado com a definição do termo ao longo dos anos, eu agora defino Lawfare como a estratégia de fazer uso - ou mau uso - da lei como um substituto para os meios militares tradicionais, a fim de atingir um objetivo operacional. Como tal, eu vejo que a lei, neste contexto, é como uma arma. Um meio que pode ser usado para fins bons ou ruins. (DUNLAP, 2008, p. 146)

A lei é vista como uma arma de guerra para punir severamente quem contraria os interesses estatais e institucionais. O Lawfare institucionaliza uma nova modalidade de guerra, não mais centrada no uso da força. Trata-se de um meio de derrotar o inimigo, utilizando-se do silêncio decorrente da aplicação da lei, vista como uma arma para justificar a efetivação da justiça social em detrimento da supressão do direito de defesa daquele inimigo processado e julgado pelo Estado. A lei é vista como instrumento autocraticamente utilizado no âmbito processual para excluir e coisificar aquele sujeito considerado inimigo do Estado, por contrariar os interesses institucionais, além de gerar instabilidade social. O terrorista, o miliciano, os chefes de organizações criminosas, os políticos que praticam atos de improbidade administrativa, os pedófilos, os agressores de mulheres, os homofóbicos, os transfóbicos são alguns dos sujeitos considerados inimigos do Estado, por contrariarem os interesses e objetivos institucionais.

Considerando-se que hoje não é mais possível eliminar esses sujeitos do sistema, por meio do uso da força física e aplicabilidade de penas cruéis e degradantes, haja vista o advento da teoria dos direitos fundamentais e direitos humanos, o Estado se utiliza de estratégias simbólicas que mascaram essa violência física, legitimando-se a institucionalização da violência por meio das normas jurídicas. $\mathrm{O}$ processo é utilizado como instrumento a serviço dos interesses do Estado e a lei é o símbolo por ele utilizado para excluir e eliminar esses sujeitos. Constrói-se simbolicamente um espaço com aparência de legalidade, pune-se autocraticamente esses sujeitos, cerceia-se o direito de defesa, mediante a limitação do contraditório e ampla defesa, já que o propósito institucional é dar uma resposta à sociedade civil, que clama por vingança e eliminação dessas pessoas consideradas transgressoras da ordem social.

Seguindo a mesma lógica implementada pelo Coronel Charles Dunlap, o Wall Street Journal publicou editorial em 28 de janeiro de 2012 definindo o Lawfare como um esforço para minar a guerra contra o terror, fazendo com que os oficiais americanos se sentissem intimidados em prosseguir com suas funções por medo de serem pessoalmente responsabilizados por seus atos. Intitulado "Lawfare Loses Big"7, o editorial do Wall Street Journal se referia à improcedência das ações propostas pela União Americana pelas Liberdades Civis - ACLU, contra ex-oficiais de defesa americanos no caso envolvendo o processo de José Padilla, condenado a 17 anos por conspiração para detonar uma bomba em solo norte-americano. Segundo o jornal, os advogados adotaram práticas de Lawfare, ou seja, não estavam interessados em justiça, mas sim em desestabilizar o combate ao terrorismo. Fica evidente a utilização da lei, nesse caso, como fonte simbólica de punição autocrática daquele sujeito considerado inimigo do Estado.

\footnotetext{
${ }^{6}$ Disponível em http://yalejournal.org/wp-content/uploads/2011/01/083111dunlap.pdf (último acesso em 2 abr. 2020)

7"But the lawyers suing for Padilla aren't interested in justice. They're practicing "lawfare," which is an effort to undermine the war on terror by making U.S. officials afraid to pursue it for fear of personal liability." - Do original 'Lawfare', loses big" - publicado em 28 de janeiro de 2012 pelo Wall Street Journal.
}

Revista de Direito Brasileira | Florianópolis, SC | v. 27 | n. 10 | p.178-200 | Set./Dez. 2020 
O objetivo é a utilização do processo como espaço de aplicabilidade de penas severas, que não condizem com o garantismo penal, pois, dessa forma, confere-se uma resposta à sociedade civil, confere-lhe uma aparente estabilidade social, em detrimento do direito de defesa. A interpretação da lei a partir de argumentos metajurídicos (axiologizantes) contribui significativamente para a implementação desse sistema processual punitivista, que não dialoga com o garantismo penal, já que seu propósito é atender aos interesses de uma sociedade civil que prima pela exclusão, marginalidade e coisificação dos sujeitos considerados inimigos do Estado.

Pelo que fora exposto até então se verifica que Lawfare é uma proposição teórica criada para legitimar o uso da lei como ferramenta de uma guerra simbólica destinada a punir severamente os sujeitos considerados inimigos do Estado (terroristas), numa clara tentativa de institucionalização de um modelo de direito fundado em bases autocráticas. Através da lei se torna viável a aplicabilidade de sanções severas contra aqueles sujeitos que contrariam aos interesses estatais e são eleitos como inimigos da coletividade, por gerarem instabilidades. Por meio da lei alcança-se a justiça social, extirpando autocraticamente do convívio social todos aqueles que representam risco à coletividade.

Nesse sentido, o que se pode concluir por meio das conceituações acima apresentadas, e diante das perspectivas abordadas até aqui, que o termo Lawfare vem sendo empregado para descrever diversos fenômenos distintos e até mesmo contraditórios, dentre os quais merecem destaque: (1) a substituição dos conflitos belicosos pelo diálogo e pela lei [John Carlson e Neville Yeomans]; (2) a implementação de técnicas jurídicas para fins de combates militares [QiaoLiang e Wang Xiangsui], e/ou, (3) a utilização da lei como instrumento para minar e desestabilizar as estratégias de combate aos "inimigos do Estado" [Charles Dunlap].

Especificamente no âmbito do objeto da presente pesquisa, pretende-se problematizar o estudo e a utilização do Lawfare no âmbito do processo penal brasileiro, investigando se há hipóteses nas quais o Estado atua no sentido de eleger inimigos, utilizando-se da lei como ferramenta de guerra para a punição autocrática de tais sujeitos. Em razão disso pode-se afirmar que no plano de aplicação do Direito há ainda uma acepção distinta do termo 'Lawfare', relacionada à utilização da lei penal como instrumento de perseguição (política, social, ideológica, religiosa e etc.). É justamente nesse contexto que se pretende trabalhar, a fim de elaborar um contraponto entre o Lawfare e a Processualidade Democrática. Nessa toada, faz-se necessário elaborar um estudo acerca da compreensão teórica de aplicação do Direito sob a perspectiva processual garantista e democrática, ideal que rompe com os modelos autocráticos de implementação da lei, utilizada para atender aos interesses institucionais que primam muito mais pela vingança perpetrada contra os inimigos do Estado, não priorizando a proteção da dignidade humana desses sujeitos.

\section{A PROCESSUALIDADE PENAL CONSTITUCIONAL COMO COROLÁRIO PARA A LEGITIMAÇÃO DAS DECISÕES JUDICIAIS NO ESTADO DEMOCRÁTICO DE DIREITO}

Com o processo de constitucionalização do direito iniciado no Brasil ao final da década de 80 , todos os ramos da ciência jurídica passaram a ser interpretados à luz da Constituição Federal. Nessa perspectiva, o estudo do direito processual sofreu um forte impacto hermenêutico, de forma que os princípios do contraditório, devido processo legal e da ampla defesa acabaram sendo alçados ao patamar de garantias fundamentais, legitimando o próprio exercício democrático da jurisdição. Nesse cenário propositivo, constata-se que pensar o processo penal sob a ótica da constitucionalidade democrática é romper com o modelo inquisitivo de processo, que coisifica o acusado a partir de argumentos e fundamentos aprioristicamente construídos com o condão de puni-lo autocraticamente. 
Essa legitimação democrática da jurisdição constitucional se deve, em parte, porque os direitos fundamentais são uma espécie de patrimônio social e, portanto, não pertencem a ideologias de esquerda, direita, ou de centro. Tratam-se, na verdade, de conquistas civilizatórias inegociáveis, de que todas as pessoas são titulares. É justamente por isso que tais conquistas devem ser respeitadas, a fim de se garantir a todos, independentemente de qualquer condição ou opção, um julgamento imparcial e calcado em princípios democráticos.

A categoria histórico-jurídica do Estado de Direito constitui a consagração de um projeto ideológico que teve em mira assegurar a liberdade e, sobretudo, a segurança dos indivíduos, mediante a demarcação dos limites entre o poder e a prepotência, a discricionariedade e arbitrariedade. [...]. Não é demais esclarecer que os direitos fundamentais são limites ao Poder. Nasceram com a clara finalidade de impedir que uma maioria conjuntural possa, com base em uma "legitimidade de origem", violar em um limite ao próprio sistema democrático. Em rigor, representam mais que um limite, já que são o próprio fundamento do sistema democrático e constitucional...”. (VALIM; COLANTUONO, 2017, p. 72-73)

O advento da constituição brasileira de 1988 trouxe uma proposta teórica que rompe drasticamente com a visão tradicional do processo até então vigente em território brasileiro, apresentando-o como uma verdadeira garantia do jurisdicionado frente à possibilidade de opressão estatal. $\mathrm{O}$ processo deixa de ser visto como mero instrumento a serviço da jurisdição, passando-se a ser visto como garantia constitucional das partes. O processo constitucional no Estado Democrático de Direito constitui-se em espaço de ampla dialeticidade dos pontos controversos da demanda, assegurando-se aos sujeitos interessados o direito de igualdade de debate e a possibilidade de influir diretamente na construção do provimento final. Pensar o processo como uma garantia constitucional decorrente da democracia é retirar das mãos do magistrado a exclusividade do poder de decidir conforme sua visão unilateral e metajurídica do caso concreto. Dessa forma, relativiza-se o protagonismo e a discricionariedade judicial, agora regrada pelos limites trazidos pela teoria dos direitos fundamentais. Nesse sentido, afirma José Alfredo de Oliveira Baracho que

o processo, como garantia constitucional, consolida-se nas constituições do século $\mathrm{XX}$, através da consagração de princípios de direito processual, com o reconhecimento e enumeração de direitos da pessoa humana, sendo que esses consolidam-se pelas garantias que os torna efetivos e exequíveis.(BARACHO, 1997, p. 106).

Se nos regimes ditatoriais que antecederam a Constituição de 1988 o processo era visto como um mero "instrumento do juiz" para a aplicação do direito material (seguindo os ensinamentos de Enrico Tulio Liebman e Oscar von Büllow), o advento da nova ordem constitucional fez com que os direitos e as garantias fundamentais passassem a exercer uma função de protagonismo dentro do ordenamento jurídico brasileiro, o que acabou se irradiando para a sistemática processual. Democratizar a forma de compreender sistematicamente o processo constitucional é colocar as partes, juntamente com o magistrado e Ministério Público, como protagonistas e responsáveis pela construção dialógica do provimento final de mérito. A decisão de mérito deixa de ser reflexo do diálogo restritamente construído entre a magistratura e o Ministério Público, retirando-se o acusado da condição de mero coadjuvante, conferindo-lhe condições de poder influir na construção discursivo-participada do mérito processual. Nesse sentido

A Constituição da República Federativa do Brasil tem como fundamento a dignidade da pessoa humana (art. $1^{\circ}$, III), regendo-se, inclusive nas relações 
internacionais, pela prevalência dos direitos humanos (art. $4^{\circ}$, II) e assegurando direitos e garantias individuais a todos os cidadãos em igualdade e sem distinção, de modo que ninguém será submetido a tortura ou tratamento desumano ou degradante (art. $\left.5^{\circ}, \mathrm{III}\right)$; que são invioláveis a intimidade, a vida privada, a honra e a imagem das pessoas (art. $5^{\circ} \mathrm{IX}$ ); que é inviolável o sigilo das comunicações telefônicas com as exceções expressas (art. $\left.5^{\circ}, \mathrm{XII}\right)$; que não haverá juízo ou tribunal de exceção (art. $5^{\circ}, \mathrm{XXXVII);} \mathrm{que} \mathrm{ninguém} \mathrm{será} \mathrm{processado} \mathrm{nem}$ sentenciado senão pela autoridade competente (art. $5^{\circ}$, LIII); que aos acusados são assegurados o contraditório e ampla defesa com os recursos inerentes ( $\operatorname{art.~} 5^{\circ}, \mathrm{LV}$ ); que ninguém será considerado culpado até o trânsito em julgado de sentença penal condenatória (art. $5^{\circ}$, LVII); assegurados ainda os direitos decorrentes do regime e dos princípios por ela adotados ou dos tratados internacionais em que seja parte a República do Brasil (art. $\left.5^{\circ} \S 2^{\circ}\right)$. (CASTILHO, 2017, p. 107)

Seguindo esta visão garantista e democrática do processo, o poder judiciário passou a ter um papel de salvaguarda dos direitos do cidadão, impedindo o abuso do Estado no exercício da jurisdição para, assim, salvaguardar os direitos fundamentais previstos no plano constituinte e instituinte. Alinhando-se a essa perspectiva, o processo penal começou a apresentar-se como um "locus" para discussão da culpabilidade à luz das garantias constitucionais limitadoras do direito de punir, exercendo seu papel garantidor de direitos, e assegurando que a punição se dê de acordo com a lei e os princípios constitucionais. O processo penal democrático-garantista objetiva resguardar os direitos fundamentais do acusado, de modo a evitar que o mesmo seja sumariamente julgado e punido. Prioriza-se o contraditório, ampla defesa, devido processo legal, que são princípios que legitimam o direito de construção dialógica do provimento final, colocando-se o acusado como protagonista do processo penal, permitindo-se o direito de participar da formação do mérito processual. Dessa forma

[...] no Estado democrático de Direito, em sua visão procedimental, não mais se poderia afirmar jurisdição como atividade do juiz no desenvolvimento do poder do Estado em direito o direito ou em aplica-lo ao caso concreto, mas sim como o resultado necessário da atividade discursiva dos sujeitos do processo a partir de argumentos internos ao ordenamento (LEAL, 2008, p. 34)

Quando Franz von Lizst cunhou a célebre expressão segundo a qual as regras penais criariam uma espécie de 'Carta Magna do Delinquente", certamente pensava em uma aplicação racional do Direito Penal (e de toda a sistemática a ele relacionada) com o intuito de impedir o "decisionismo" e, consequentemente, o abuso na aplicação da violência estatal (LEAL, 2008). Dessa forma, a análise das questões penais dentro do Estado Democrático de Direito, como é o caso do Brasil, deve se dar através do processo judicial, respaldada pelo princípio do devido processo legal (art. $5^{\circ}$, LIV da CF) e amparado pelo contraditório, a ampla defesa, a isonomia das partes, o juiz natural e o duplo grau de jurisdição.

Em uma concepção democrática de direito, torna-se fundamental que o sistema de tomada de decisões se estabeleça de forma a permitir a fiscalização do provimento final pela sociedade, possibilitando, inclusive, que se faça a contestação aos argumentos utilizados na sentença, através de mecanismos de revisão próprios. A jurisdição constitucional contrapõe-se à autocracia jurisdicional, que coloca o magistrado como protagonista do processo e o legitimado exclusivo para decidir aprioristicamente a lide conforme suas percepções metajurídicas. Sob o viés da processualidade democrática, a utilização da racionalidade crítica passa a ser o referencial das decisões judiciais, que não admitem mais a interpretação da lei fundada em juízos valorativos que objetivam a punição sumária do acusado.

O respeito ao contraditório e à ampla defesa no processo de tomada de decisão judicial é consectário lógico da democracia, posto que a legitimação do provimento jurisdicional somente se 
dá mediante a efetivação dos preceitos processuais insculpidos na norma constitucional e, ainda, nos tratados internacionais, que visam à proteção dos direitos humanos. A exauriência argumentativa dos pontos controversos da demanda, realizada pelas partes interessadas, é o que assegura a legitimidade democrática do provimento final de mérito. Qualquer decisão judicial contrária aos respectivos princípios ocasiona o error in procedendo, cuja consequência é a declaração de nulidade do ato processual proferido contrariamente aos direitos do acusado.

Assim sendo, quem garante a legitimidade democrática do provimento jurisdicional é a obediência irrestrita ao processo judicial e aos princípios a ele inerentes, bem como o reconhecimento do direito de as partes serem coautoras do conteúdo de mérito debatido judicialmente. Nesse sentido, é importante lembrar os ensinamentos de Luiz Flávio Gomes, que ressalta o fato de que "a legitimação democrática do poder judiciário é estruturalmente diversa da dos demais poderes do Estado, não tendo nada que ver com a vontade nem com a opinião da maioria" (GOMES, 1997, p. 120). A vontade unilateral do julgador e o clamor social não podem ser os únicos critérios hábeis a permitir democraticamente a construção do provimento final, já que a participação dos sujeitos interessados é de fundamental importância para a legitimidade democrática do referido provimento, que deve ser reflexo da análise racional dos fundamentos da pretensão.

Em uma democracia só há lugar para provimentos jurisdicionais construídos mediante a estrita obediência ao procedimento previamente estabelecido em lei. Dessa forma, a decisão deve ser reflexo do exercício do contraditório, da ampla defesa, da isonomia processual, do devido processo legal e da obrigatoriedade de fundamentação jurídica coerente com a pretensão deduzida, evitando o subjetivismo e o decisionismo que, a bem da verdade,

é mero reflexo de uma concepção autocrática e de um modelo de processo que se desenvolve a partir do entendimento teórico de que a jurisdição é uma atividade pessoal do magistrado, cuja legitimação decorre de argumentos e de fundamentos pressupostos que coincidem com a sacralização e a divinização da pessoa do julgador. A construção de todo o pensamento teórico concernente, especificamente, ao processo e à jurisdição, encontra-se diretamente vinculado à autoridade do juiz, pessoa dotada, no entendimento da maioria dos estudiosos, de uma sabedoria inata capaz de diluir e solucionar os conflitos de interesses a partir de sua percepção individual, pressuposta e inata sobre o que é justo. (COSTA, 2017 , p. 38)

Nessa esteira, o ato judicial só se legitima pela via discursiva exercida através de um procedimento aberto a todos os interessados no provimento final, posto que "a decisão no direito democrático é processualmente procedimental e construída a partir da legalidade procedimental aberta a todos os indivíduos e se legitima pelos fundamentos teórico-jurídicos do discurso democrático nela contidos" (LEAL, 2002, p. 101-102). O que se deve prezar, portanto, é pelo respeito às etapas autônomas e independentes dos procedimentos de investigação e cognição, estabelecendo um círculo virtuoso em que a legitimidade constitucional se irradie por todo o procedimento de análise da ocorrência de um crime, incluindo o veredito final. Nessa perspectiva propositiva,

Em suma, o processo só é substancialmente justo quando as medidas e providências próprias de seu andamento correlacionam-se logicamente com o bloco de constitucionalidade ou quando substancialmente observados os critérios e pressupostos constitucionais relacionados acima, tendo a resultante conteúdo igualmente compatível com o rigor da premissa, da licitude e legitimidade de todo o desenvolvimento do processo, já que a evidência da injustiça é a da incompatibilidade em qualquer grau ou momento da atuação processual, com os princípios vetores dos preceitos dessa natureza. A prova do processo justo então 
cabe ao acusador, e não a do injusto pelo acusado. (CASTILHO, 2017, p. 110111)

Conclui-se, então, que existe o direito fundamental a um processo justo, democrático e isento, o que decorre das próprias características da Constituição Federal. Decisão judicial justa é aquela construída em bases democráticas, que prima pela observância dos princípios constitucionais do processo (contraditório, ampla defesa, devido processo legal e fundamentação racional), oportunizando aos interessados o igual direito de construir dialeticamente o conteúdo meritório do provimento final. Nesse sentido, o processo deve atuar de forma a impedir o arbítrio estatal, evitando-se que o jus puniendi seja utilizado como mecanismo de opressão e perseguição, como será visto a seguir.

\section{O LAWFARE COMO INSTRUMENTO DE PERSEGUIÇÃO E A OFENSA AO PROCESSO PENAL CONSTITUCIONAL}

$\mathrm{Na}$ perspectiva processual penal o lawfare pode se referir ao processo de instrumentalização da lei para alcançar fins políticos, deslegitimando ou incapacitando determinadas pessoas ou grupos mediante uma aplicação heterodoxa do direito penal e das regras processuais a ele inerentes. Consiste na utilização da lei como instrumento de guerra ideológica contra os sujeitos considerados inimigos do Estado. Nesse viés, o processo penal autocrático é utilizado como ferramenta para legitimar pressupostamente a aplicabilidade do respectivo instituto (lawfare) para, assim, alcançar as finalidades estatais previamente estabelecidas, que consistem em perseguir, excluir, punir autocraticamente aqueles sujeitos eleitos como inimigos do Estado.

Pode-se dizer que a prática do lawfare se manifestaria por meio da manipulação das leis, dos procedimentos e dos entendimentos jurisprudenciais, com o objetivo de atingir determinados setores, indivíduos ou organizações qualificadas como "inimigos políticos". A sua prática se faz notar, ainda, pela espetacularização das punições e pela convalidação de medidas arbitrárias e ilegais em nome de uma necessidade de combate à criminalidade, o que fere de morte os princípios constitucionais e dá ensejo a uma flexibilização circunstancial das garantias fundamentais. Traficantes de drogas, chefes de organizações criminosas, políticos envolvidos em escândalos de corrupção, milicianos, homens que praticam violência contra as mulheres são alguns exemplos que ilustram as diversas categorias dos sujeitos eleitos como inimigos políticos do Estado. Visando atender ao sentimento de vingança social, que preza pela eliminação e exclusão desses sujeitos, o próprio Estado se utiliza do processo e da lei para decretar uma guerra simbólica, cujo objetivo é punir exemplarmente esses sujeitos, em contrariedade aos princípios constitucionais que regem o processo penal garantista e democrático.

Em um espaço conflituoso e eminentemente hostil, como aquele em que costumam se dar os embates penais, a manipulação circunstancial dos entendimentos jurisprudenciais e da aplicação das leis, transformando-os em instrumento de perseguição, afigura-se como uma ofensa aos princípios democráticos que devem reger o processo penal. A hermenêutica é utilizada pelos julgadores e Ministério Público para a construção simbólica de interpretações e argumentações retóricas que privilegiam a eliminação silenciosa (não bélica) desses sujeitos. Constrói-se o que se denomina "jurisprudência defensiva", reflexo de interpretações antidemocráticas, pois a lei é utilizada como um símbolo de exclusão e marginalidade daqueles que agem contrariamente aos interesses estatais e, por isso, são categorizados como inimigos do Estado. O processo construído a partir das matrizes trazidas pelo lawfare funda-se na autocracia e discricionariedade judicial, que prima pelo protagonismo do julgador na interpretação e aplicação da lei, já que não permite que o acusado construa dialeticamente o provimento final de mérito.

Como visto anteriormente, a Constituição Federal fixou balizas a serem observadas no curso da ação penal - e até mesmo antes dele, na fase de investigação -, atuando de maneira a 
salvaguardar direitos e garantias fundamentais, limitando o poder de atuação do Estado em face do indivíduo. Dessa forma, o enfrentamento da criminalidade só pode ser realizado mediante respeito irrestrito aos princípios que norteiam a aplicação do processo penal.

Ainda que animados de boas intenções, aos agentes públicos incumbidos da persecução dos atos de corrupção não é dado transgredir as normas jurídicas. Não há alternativa à legalidade democrática. Trata-se de uma disjuntiva impossível. Em outras palavras, só pode haver enfrentamento da corrupção dentro dos limites do Estado de Direito (VALIM; COLANTUONO, 2017, p. 74)

Em muitos casos, a pretexto de combater crimes graves, verifica-se a adoção de entendimentos jurisprudenciais que buscam mitigar direitos e garantias fundamentais. A justificativa para tais fatos seria a pretensa excepcionalidade das situações que se apresentam. A restrição do garantismo penal se justificaria em razão da gravidade da conduta delitiva, premissa essa muito utilizada para explicar a aplicabilidade do instituto do lawfare no judiciário brasileiro. Tem se tornado comum a presunção da culpabilidade dos "ditos inimigos do Estado", que quando processados não gozam da garantia constitucional da presunção de inocência, já que são recebidos desde o início da ação penal como "culpados".

É o que acontece nas ações penais propostas contra políticos acusados dos diversos crimes relacionados com a suposta apropriação ou utilização indevida de "dinheiro público". Tais sujeitos, quando denunciados pelo Ministério Público, precisam provar sua inocência, já que no âmbito do processo penal fundado em bases do lawfare, o que se presume é a culpabilidade, não a inocência. Tais acusados chegam no judiciário com a "pecha de corruptos", desonestos e inimigos simbólicos do Estado, por terem supostamente praticado crimes contrários aos interesses da sociedade. Visando buscar uma punição exemplar, que atenda aos interesses e anseios sociais, o judiciário se utiliza da lei como instrumento de uma "guerra simbólica", interpretando e aplicando-a contrariamente ao garantismo penal, visto que o objetivo central é a punição tão esperada pela sociedade civil.

Muitas vezes essas técnicas interpretativas são utilizadas como forma de oprimir determinados indivíduos e/ou programas ideológicos, lançando mão do aparato legislativo e judicial estatal simplesmente para perseguir aqueles que possuem um determinado posicionamento ideológico contrário aos interesses estatais, numa clara institucionalização do modelo autocrático de processo. No âmbito judicial, a prática do lawfare acaba sendo acentuada pela concepção autocrática do modelo de persecução penal, calcado na ideia de que a sentença é uma atividade individual do julgador (podendo ser legitimada por argumentos axiológicos e de caráter estritamente pessoal).

A implementação do lawfare é incompatível com uma hermenêutica constitucional democrática, posto que sua consequência é a transformação do processo penal em instrumento do juiz para aplicação de suas convicções pessoais, dispensando uma análise eminentemente jurídica, racional, garantista e democrática do caso concreto.

Ao entregar exclusivamente ao magistrado o direito/dever de "fazer justiça", a partir dos anseios e expectativas sociais, cria-se a possibilidade de implementação de um modelo de processo judicial perseguidor, opressor, autocrático e limitador de garantias fundamentais, o qual se afigura como sendo totalmente incompatível com o Estado Democrático de Direito. Resgata-se, assim, o processo inquisitivo, cujas funções de acusar e julgar concentram-se nas mãos de uma mesma pessoa ou instituição. Nos dizeres de Richard A. Clarke, o inimigo do Estado e da sociedade é uma construção ideológica que se dá com o objetivo de robustecer o poder estatal (2004), ressaltandose o papel do Judiciário na ratificação de todos esses propósitos estatais.

Constitucionalmente o poder judiciário tem o dever de agir com independência, liberto de quaisquer influências externas, pautando-se no cumprimento das normas democraticamente vigentes. Daí que se diz que a atuação estatal na repressão à criminalidade deve ser feita de forma 
a garantir o absoluto respeito aos direitos fundamentais. O processo penal garantista é um recinto em que o acusado pode legitimamente resistir aos arbítrios praticados pelo Estado opressor e que privilegia o ius puniendi.

A crítica proposta na presente pesquisa reside na exacerbada carga axiológica e metajurídica utilizada pelo poder judiciário quando do julgamento daquelas demandas que envolvem os denominados "inimigos do Estado e da sociedade civil". Nesses casos a lei é um instrumento simbolicamente utilizado pelo Estado para perpetrar o processo autocrático e punir exemplarmente o agente, conforme os interesses sociais. No momento em que o julgador privilegia a interpretação da lei com o objetivo de punição do acusado, tem-se a limitação do espaço processual de debate dos pontos controversos da demanda, impede-se o direito de formação participada do mérito processual, suprimem-se os princípios constitucionais do processo, além de enaltecer o protagonismo e a discricionariedade judicial em detrimento dos interesses do acusado.

$\mathrm{O}$ processo penal garantista deve ser compreendido e interpretado de forma isonômica e isomênica ${ }^{8}$, ou seja, a todos os sujeitos do processo devem ser assegurados iguais direitos de interpretação e aplicação racional da norma jurídica ao caso concreto. O Estado, na pessoa do magistrado, não pode gozar do privilégio de interpretação valorativa do caso concreto, sob a justificativa de atender aos clamores sociais. Admitir que o processo penal seja conduzido a partir dos anseios de uma sociedade que clama por vingança é o mesmo que legitimar o direito de o julgador interpretar livremente a norma jurídica a ser aplicada no caso concreto, constituindo-se, assim, a adoção exata do instituto do lawfare. A imparcialidade do julgador é corolário da fundamentação racional da decisão judicial, além de constituir importante instrumento que garante a proteção constitucional da dignidade da pessoa humana do acusado. Nesse sentido

Como regra, ao Poder Judiciário foi concedido o monopólio da jurisdição. O propósito da jurisdição é o de resolver conflitos intersubjetivos de interesses, substituída a força pela razão na resolução do conflito de interesses; mas para que isso funcione, seja aceito e tenha credibilidade é necessário que o magistrado, isto é, o agente público legitimamente investido na função de aplicar o direito, seja imparcial, isto é, não tenha nenhum interesse próprio, particular, pessoal, na resolução daquela lide e a julgue de acordo com sua convicção racionalmente demonstrada. Essa ideia se aplica na jurisdição penal com maior rigor, na medida em que ela - a jurisdição penal - decide se acolhe ou não a pretensão punitivista do Estado de aplicar sanções privativas de liberdade ao indivíduo. Não é à toa, portanto, que toda a estrutura do Poder Judiciário está alicerçada sobre o valor da imparcialidade do magistrado, pois ela constitui a principal fonte de legitimidade do Poder Judiciário para solucionar conflitos de interesse. (ROCHA, 2017, p. 161)

Quando um magistrado, por livre convencimento, deixa de observar a constituição e motiva suas decisões em fundamentos metajurídicos, eivados de caráter meramente axiológicos e de um senso de justiça meramente pessoal, verifica-se um claro desvio de finalidade no processo constitucional, comprometemdo-se a integridade das decisões, colocando em risco a própria democracia, além de constituir direta afronta à dignidade humana do acusado. $\mathrm{O}$ processo penal garantista funda-se nos fatos, e não na pessoa do acusado, considerando-se que a partir da interpretação extensiva do princípio da presunção de inocência deve-se analisar, no âmbito da cognição exauriente, se as provas produzidas são suficientes a desconstituir a presunção constitucional de não culpabilidade conferida ao acusado. A partir dessas proposições, ressalta-se

É possível assim vislumbrar o desvio de finalidade ou de motivação pela constatação do próprio andar do processo, o que, por exemplo, se pode perfeitamente observar quando a investigação dá prevalência ao foco na pessoa e

\footnotetext{
${ }^{8}$ Isomenia é a igualdade conferida às partes no que tange à exauriência argumentativa no âmbito processual. Revista de Direito Brasileira | Florianópolis, SC | v. 27 | n. 10 | p.178-200 | Set./Dez. 2020
} 
não nos fatos, hipótese que a doutrina costuma identificar como direito penal do autor ou Direito Penal do inimigo, e onde os fatos e sua apuração, mesmo quando importantes, ficam sendo relegados a um segundo plano ou plano inferior da investigação, tanto na cogitação investigativa mas principalmente na atuação do autor da demanda penal e por parte do julgador envolvido no dilema processual e pela politização da lide. Também revela o desvio cogitado quando há excessiva exposição dos agentes do delito ou as características da conduta do agente são mais realçadas e importantes que o respectivo resultado jurídico penal em si, sendo os elementos de caráter psicológico muitas vezes mais discutidos que os dados ou elementos materiais relacionados aos fatos investigados. Percebe-se, ainda, o desvio de finalidade ou de motivação quando o processo revela a prevalente necessidade de identificação do responsável ou a autoria mais do que a figuração dos fatos, muitas vezes invertendo a investigação para alcançar o agente e até mudando ou alterando os fatos, consciente ou inconscientemente, evento bastante comum de modo geral nos crimes ligados ao tráfico de entorpecentes, ou aos crimes contra a dignidade sexual de conhecida sensação social. Mais recentemente, no âmbito dos crimes de corrupção, lavagem de dinheiro e crimes financeiros ou tributários de repercussão, a identificação dos autores tem assumido seguidamente mais importância para os condutores do processo que os fatos que terá de revelar como base para o julgamento num processo justo como se, desvendada a autoria, pouco restasse para o resultado da causa. (CASTILHO, 2017, p. 110).

A lei e a constituição brasileira vigente deve funcionar como limites ao poder de punição do Estado, tendo a finalidade de impedir a violação de direitos e garantias fundamentais e criando os pilares de sustentação para a perpetuação da democracia. Assim, o que dificulta a aceitação do lawfare no âmbito do processo penal é que a "caça aos inimigos" por ela propostas se calca em um discurso que pretende legitimar ofensas graves a direitos e garantias individuais, sob o pretexto de que tais medidas se fazem necessárias ao combate à criminalidade e a satisfação dos anseios sociais. Não resta dúvida de que os atos de corrupção e outros comportamentos criminosos merecem o repúdio da sociedade e, portanto, devem ser punidos na forma da lei. Ocorre, portanto, que essa punição não pode se fazer acompanhar de violações a direitos fundamentais. Dessa forma, o direito penal deve, acima de tudo, prezar pelo respeito aos limites estabelecidos pelo Estado de Direito.

Pensar o processo judicial a partir dos anseios sociais é utilizar uma metodologia de interpretação do espaço processual contrariamente às diretrizes constitucionais. Tal afirmação se justifica porque, sob a ótica do processo penal garantista, o julgador deve se ater aos fatos discutidos em juízo, não ao nome da pessoa acusada. Tais fatos devem ser analisados e interpretados em conformidade com os princípios regentes do processo, quais sejam, contraditório, ampla defesa, devido processo legal, fundamentação racional e presunção de inocência ou não culpabilidade. A partir dessas premissas expostas, fica evidente que o processo não pode ser visto como uma ferramenta à disposição para atender aos interesses utilitaristas de uma sociedade que busca vingança, exclusão e marginalidade daquelas pessoas por ela consideradas inimigas do Estado. O lawfare funda-se exatamente nessa perspectiva teórica, qual seja, utiliza-se da lei como instrumento simbólico de decretação de uma guerra silenciosa contra aqueles que contrariam os interesses estatais, ressaltando-se que o processo é visto apenas como meio para atender esses fins.

Valendo-se de argumentos inverídicos, mas verossimilhantes, os propagadores das práticas de lawfare se escondem atrás de máscaras ideológicas, a fim de se utilizarem do processo penal como instrumento legitimador da perseguição, o que acaba solapando a confiança nas instituições democráticas. Nesse sentido, aliás, é importante lembrar que o poder judiciário não deve se imiscuir em política, devendo se restringir a fazer uma análise do direito à luz da Constituição Federal. É por esse motivo, aliás, que Geraldo Ataliba lembra que o sistema constitucional brasileiro optou por uma magistratura profissional que, em regra, ingressa nos 
quadros da administração pública por meio de concurso de provas e títulos, independentemente de indicação política:

Deveras, a teoria da tripartição do poder - tal como formulada classicamente no moderno constitucionalismo e tal como por nós adotada - demonstra que não há nenhuma necessidade- mas, pelo contrário, até inconvenientes - em os membros do Poder Judiciário serem escolhidos pelo povo. Se a função judicial restringe-se à interpretação das leis - no sentido amplo, começando pela lei constitucional, então não há razão para que o instituto representativo se faça sentir na seleção dos cidadãos que irão servir no Poder Judiciário. As funções técnicas não devem ser representativas, porque são não-políticas. (ATALIBA, 2004, p. 112)

A fim de evitar qualquer desvio de finalidade no exercício da jurisdição, a magistratura acabou sendo agraciada com várias prerrogativas, dentre as quais se destacam a inamovibilidade, irredutibilidade dos vencimentos e vitaliciedade, conforme expressamente previsto no art. 95 da Constituição Federal. Essas garantias dadas ao magistrado foram instituídas a fim de assegurar aos juízes a tranquilidade necessária para que possam exercer suas atribuições com imparcialidade, independentemente de pressões externas. Nas lições de Luigi Ferrajoli

o juiz não deve ter qualquer interesse, nem geral nem particular, em uma ou outra solução de controvérsias, que é chamado a resolver, sendo sua função decidir qual delas é verdadeira qual é falsa. Ao mesmo tempo ele não deve ser um sujeito 'representativo', não devendo nenhum interesse ou desejo - nem mesmo da maioria da totalidade dos cidadãos - condicionar seu julgamento que está unicamente em tutela dos direitos subjetivos lesados (FERRAJOLI, 2014, p. 534)

Ocorre, no entanto, que a implementação do lawfare no âmbito judicial, muitas vezes, decorre de uma ideologia influenciada por um ódio irracional direcionado a um determinado grupo político ou classe social, gerando o entendimento de que os "inimigos" não são pessoas dignas de direitos e garantias e, portanto, não devem fazer jus à sistemática de proteção constitucional que se aplica aos "cidadãos de bem". possa ser feita em detrimento do respeito dos direitos e garantias individuais, sobretudo porque os movimentos de mitigação circunstancial de direitos partem do pensamento de classes dominantes, sendo maximizados pela mídia.

Atualmente, constata-se uma exploração exaustiva das práticas criminosas por meio de reportagens, responsáveis por incutir na população a cultura de que a solução para os problemas sociais do Brasil passa pela punição exacerbada daqueles que praticam atos criminosos. Insatisfeita, a sociedade acaba "aceitando" abrir mão de conquistas jurídicas, reclamando o recrudescimento das penas e a ampliação do espectro punitivista estatal, calcando-se no falso argumento de que tais medidas acarretarão na diminuição de delitos.

É justamente com o fim de dar uma resposta aos clamores populares e beneficiar-se disso, que alguns órgãos essenciais à justiça têm iniciado uma campanha teórica pela mitigação de garantias individuais dos "inimigos" do povo. Lançando mão de argumentos contrários a direitos constitucionalmente resguardados, ofertam ao povo uma solução pautada em relativismos constitucionais, para solucionar o caos político que parece ter se instaurado no país.

Ocorre, entretanto, que a partir do momento em que o direito processual penal passa a servir como campo de manobra para a implementação do lawfare, passa a carecer de legitimidade perante a ordem democrática, que cada vez mais vai se tornando amputada, condicionada e limitada. Embora já tenha sido demonstrado que as garantias individuais carregam o sangue

\footnotetext{
${ }^{9}$ Ironicamente o termo "Cidadão de Bem" (GoodCitizen) era o nome de um jornal fundado em 1913 que apoiava a
} KuKluxklan 
daqueles que lutaram pelos ideais que hoje se encontram enraizados nas Constituições de vários países ao redor do mundo, verifica-se que são elas que mais têm sofrido com o lawfare. A população, amedrontada e guiada por uma retórica irracional (mas convincente), abre mão de suas garantias, dando sinal verde para a mitigação de princípios e direitos fundamentais. Agindo dessa forma, se omite e fornece espaços ao fortalecimento de um poder autocrático institucionalizado, que se estabelece em detrimento dos direitos dos cidadãos.

\section{MODELO DE PROCESSO CONSTITUCIONAL E A FORMAÇÃO PARTICIPADA DO MÉRITO PROCESSUAL COMO MEIO DE DEMOCRATIZAR A CONSTRUÇÃO DO PROVIMENTO FINAL MEDIANTE A PARTICIPAÇÃO DIALÓGICA DAS PARTES INTERESSADAS}

A constitucionalização no estudo do processo, visto como lócus de discursividade ampla das questões controversas que integram a demanda, é o referencial teórico para o estudo crítico do objeto da respectiva pesquisa. Ultrapassar a visão técnico-instrumentalista, fundada no modelo de processo autocrático, cujo referencial é a autoridade do julgador, constitui um meio de problematizar criticamente o estudo do instituto do lawfare, especialmente para demonstrar que o direito de as partes participarem da construção da decisão de mérito constitui um meio de assegurar o caráter democrático da decisão. "Os espaços de interlocução são vistos como locus de formação de opiniões dos cidadãos por meio de redes de discussões que visam construir o consenso coletivo e a gestão dos dissensos", visto que a partir dessas proposições são oferecidos "subsídios, conteúdos e critérios para deliberações participadamente tomadas e que venham a atender o interesse da coletividade" (COSTA, 2012, p. 2009).

O princípio da supremacia da Constituição emerge como garantia fundamental do devido processo constitucional (DIAS, 2010, p. 82), ressaltando-se que a teoria constitucional do direito democrático somente será compreensível se fundada nas bases legitimantes da cidadania e soberania popular (LEAL, 2009, p. 86). O processo constitucional democrático é um contraponto ao modelo autocrático de processo adotado no julgamento do mérito das ações penais em que se tem a aplicabilidade do lawfare no Brasil. O protagonismo judicial é revisitado por proposições teóricas que compreendem o processo como um espaço de debate amplo das questões controversas pelos interessados no provimento. Os princípios do contraditório, da ampla defesa, devido processo legal e isonomia processual regem a estrutura procedimental do debate da pretensão no âmbito processual pelas partes interessadas. "O processo na Teoria do direito democrático é o ponto discursivo da igualdade dos diferentes" (LEAL, 2002, p. 75). É no âmbito processual que se deve assegurar às partes interessadas o efetivo direito de argumentar, participar e garantir a coautoria de decisões que irradiam efeitos jurídicos diretos ou indiretos na esfera individual ou coletiva de cada sujeito. É "oportunizar a discussão de todos os interessados, garantindo-se a construção de um espaço procedimentalizado em contraditório, a fim de afastar protagonismos e a busca solitária pela aplicação do direito com justiça" (PAOLINELLI, 2014, p. 52).

A formação participada do mérito no âmbito do processo penal democrático decorre de proposições teóricas que revisitam criticamente o modelo de processo autocrático-inquisitivo. $\mathrm{Ou}$ seja, assegurar aos interessados a igualdade de oportunidade de participação na construção discursiva da decisão de mérito constitui um meio hábil de garantir que o provimento jurisdicional será democrático, visto que não decorrerá apenas da visão unilateral e solipsista do julgador.

As partes que integram o espaço processual, bem como todos os demais sujeitos afetados pelos efeitos jurídicos do provimento final, possuem direito legítimo de participarem dialeticamente da construção do conteúdo decisório. Negar o direito de as partes participarem na construção da decisão de mérito é reproduzir um modelo de processo centrado na autoridade do julgador e na discricionariedade judicial. Especificamente no âmbito do processo penal fundado nas bases trazidas pelo lawfare, verifica-se que restringir o debate processual da pretensão apenas 
na pessoa do magistrado e representante do Ministério Público torna a decisão final de mérito autocrática, já que todos aqueles afetados pelos efeitos jurídicos do provimento final ficam impossibilitados de argumentar e debater os pontos controversos da demanda.

O estudo da formação participada do mérito processual, no contexto da presente pesquisa, justifica-se em razão da necessidade de análise do tema lawfare sob a perspectiva da processualidade democrática. Pretende-se demonstrar que os julgamentos construídos dogmaticamente a partir de percepções metajurídicas, irracionais e unilaterais do julgador impossibilita o direito de o acusado participar discursivamente da construção do provimento final. No momento em que os sujeitos que sofrem os efeitos jurídicos da decisão final ficam impossibilitados de participar da construção da referida decisão, tem-se um modelo de processo inquisito-autocrático, contrário às diretrizes democráticas trazidas pela constituição brasileira de 1988.

A argumentação processual pelas partes interessadas no provimento consiste em implementar a igual oportunidade de interpretação da lei a todos, ou seja, "erige ao julgador vedação a recursos interpretativos extrassistêmicos" (GRESTA, 2014, p. 191). É nesse contexto argumentativo que advém os estudos do processo penal democrático no modelo participativo. A democracia é um paradigma de Estado que preconiza o exercício amplo das liberdades dos cidadãos orientarem-se por meio da participação nos processos deliberativos dos quais resultam decisões que poderão afetar toda a coletividade e o sujeito que sofrerá diretamente os efeitos jurídicos da pena a ele aplicada. A autodeterminação democrática é corolário do exercício da cidadania pelo princípio participativo.

Ser cidadão, no contexto da processualidade democrática, é ter a possibilidade de influenciar diretamente no conteúdo da decisão, a partir do direito legitimo de discussão do conteúdo meritório da demanda. Outro ponto relevante a ser ressaltado é que, tanto a participação no processo quanto o direito de amplo controle do conteúdo de todos os provimentos estatais somente serão corolários do exercício pleno da cidadania se os sujeitos estiverem isonomicamente no mesmo plano processual de argumentação fático-jurídica da pretensão. O mérito processual será democraticamente construído se a participação dos interessados for livremente exercida e desenvolvida no sentido de efetivar a ampla físcalização da atividade do julgador no ato de decidir.

As proposições que teorizaram o direito democrático são produto da instauração do discurso no plano instituinte e constituinte, uma vez que "a positivação do direito democrático não parte de uma ontologia ínsita à norma (nomogênese), como preconizam os jusnaturalistas, os fenomenologistas e os realistas, em suas múltiplas e engenhosas vertentes conjecturais, mas é elaborado no recinto discursivo de juridificação procedimental definidora dos critérios de produção, aplicação e garantia de direitos” (LEAL, 2002, p. 75-76).

Nesse ínterim, o processo deixa de ser visto como mero instrumento ${ }^{10}$ para o exercício da jurisdição e de proclamação da vontade do julgador como o único legitimado a decidir, e passa a redesenhar sua finalidade na perspectiva em que o compartilhamento do centro das decisões passou

\footnotetext{
${ }^{10}$ Quando Cândido Rangel Dinamarco proclama, ao se contrapor a Fazzalari, que a diferença entre ambos "é que o professor de Roma põe o Processo ao centro do sistema" enquanto a proposta é que "ali se ponha a jurisdição", conclui-se facilmente que o insigne professor paulista e seus inúmeros discípulos, em todo o Brasil e no mundo, ainda não fizeram opção pelo estudo do direito democrático, pensando ainda ser o plano da DECISÃO exclusivo do decididor (juiz) e não um espaço procedimental de argumentos e fundamentos processualmente assegurados até mesmo para discutir a legitimidade da força do direito e dos critérios jurídicos de sua produção, aplicação e recriação.

Em face da teoria constitucional legalmente adotada na Constituição brasileira de 1988, o momento decisório não é mais a oportunidade de o juiz fazer justiça ou tornar o direito eficiente e prestante, mas é o instante de uma DECISÃO a ser construída como resultante vinculada à estrutura procedimental regida pelo PROCESSO constitucionalizado. Nessa perspectiva, que é de direito democrático, o processo não é instrumento da jurisdição ou mera relação jurídica entre partes e juiz, porque é instituição-eixo do princípio do existir do sistema (aberto) normativo constitucionaldemocrático e que legitima o exercício normativo da jurisdicionalidade em todas as esferas de atuação do Estado que, por sua vez, também se legitima pelas bases processuais institutivas de sua existência constitucional (LEAL, 2002, p. 68-69).
} 
a legitimar todos os interessados na construção discursivo-democrática do conteúdo que integrará o mérito do provimento jurisdicional. Buscou-se, com isso, instituir o discurso democrático como o referencial teórico para o estabelecimento de critérios jurídicos da decisão judicial compartilhada. A teoria neo-institucionalista do processo $^{11}$, de autoria do jurista mineiro Rosemiro Pereira Leal, de cunho dialógico-popular, propõe o estudo do processo como uma instituição constitucionalizada hábil a assegurar irrestritamente o controle dos procedimentos político-jurídicos, num espaço discursivo-processualizado que legitima o exercício da cidadania.

O modelo constitucional do processo, tal como apresentado no presente contexto, representa um contraponto ao protagonismo e discricionariedade judicial. O processo não pode ser visto como um espaço em que o magistrado se utiliza de seu poder para interpretar autocraticamente a norma jurídica e aplicá-la de acordo com os clamores sociais. No momento em que o processo se torna um espaço de reprodução dos ideais da sociedade, permitindo-se que o julgador se utilize de critérios axiológicos para decidir, tem-se o comprometimento do garantismo penal, além do cerceamento de defesa do acusado. "Combater a discricionariedade, o ativismo, o positivismo fático [...[ - que, como se sabe, são algumas faces do subjetivismo - quer dizer compromisso com a Constituição e com a legislação democraticamente construída, no interior da qual há uma discussão, no plano da esfera pública, das questões ético-morais da sociedade" (STRECK, 2012, p. 110).

A legitimidade democrática de um provimento jurisdicional é comprometida, de forma significativa, pelo protagonismo judicial, ou seja, "a crítica à discricionariedade judicial não é uma proibição de interpretar", tendo em vista que "o drama da discricionariedade que critico reside no fato de que esta transforma juízes em legisladores", considerando-se que "esse poder discricionário propicia a criação do próprio objeto de conhecimento, típica manifestação do positivismo" (STRECK, 2012, p. 93). O lawfare (a lei como ferramenta hábil a ser aplicada para derrotar o inimigo do Estado) é um instituto que fortalece a discricionariedade e o protagonismo judicial, pois legitima o julgador a se utilizar de argumentos metajurídicos e axiológicos para punir autocraticamente aqueles sujeitos que o Estado enxerga como inimigo. Em razão disso, fica afastada a possibilidade de formação participada do mérito processual, comprometendo-se o garantismo penal e robustecendo a autocracia jurisdicional.

\section{CONCLUSÃO}

Os desafios para a sistematização teórica de um modelo de processo penal democrático, garantista e constitucionalizado passa diretamente pela ressignificação das perspectivas instrumentalistas, fundadas num modelo de processo que legitima pressupostamente o poder do juiz decidir de forma metajurídica, axiológica e voltada a atender aos clamores sociais. O processo inquisitivo-autocrático é aquele em que o julgador tem amplos poderes de decidir; fundamenta suas decisões em argumentos metacientíficos e distantes da racionalidade crítica; não assegura aos sujeitos do processo o direito de participação na formação do mérito processual e coloca as partes como coadjuvantes do debate processual, haja vista a prevalência do protagonismo e da discricionariedade judicial.

O instituto do lawfare é uma construção teórica que possui estreito diálogo com o modelo de processo autocrático e instrumentalista. Etimologicamente a expressão lawfare possui relação direta com as expressões "lei" e "guerra", ou seja, a lei é um instrumento utilizado para a realização de uma guerra simbólica, pois o Estado objetiva eliminar, marginalizar e punir autocraticamente seus inimigos. Seu principal fundamento encontra-se no direito norte-americano, especialmente

\footnotetext{
${ }^{11}$ [...] o que se busca com uma teoria neo-institucionalista do processo é a fixação constitucional do conceito do que seja juridicamente processo, tendo como base produtiva de seus conteúdos a estrutura de um discurso advindo do exercício permanente da cidadania pela plebiscitarização continuada no espaço processual das temáticas fundamentais à construção efetiva de uma Sociedade Jurídico-Política de Direito Democrático (LEAL, 2009, p. 89) (grifo nosso). Revista de Direito Brasileira | Florianópolis, SC | v. 27 | n. 10 | p.178-200 | Set./Dez. 2020
} 
após o atentado de 11 de setembro de 2001, momento em que sedimentou o entendimento no qual a lei foi a ferramenta estrategicamente utilizada para punir severamente os terroristas, considerados os inimigos do Estado e da sociedade civil. Como não era mais possível a decretação de uma guerra bélica e pautada no uso da força, haja vista a vigência da teoria dos direitos humanos, a lei passou a ser utilizada como o instrumento para a decretação dessa guerra institucionaliza e simbólica contra os sujeitos considerados "inimigos do Estado e da sociedade civil".

No Brasil a Portaria 666, de 25 de julho de 2019, editada pelo então Ministro da Justiça, Sérgio Moro, institucionaliza o lawfare, ao reconhecer a possibilidade de deportação ou repatriação sumária dos inimigos do Estado (como é o caso dos sujeitos suspeitos de envolvimento em terrorismo, organizações criminosas, tráfico de drogas e armas, pornografia ou exploração sexual infanto-juvenil e torcida com histórico de violência em estádios de futebol).

A principal crítica que se faz ao instituto do lawfare é que o mesmo resgata o modelo de processo inquisitivo, fortalece os poderes do julgador e permite que a lei seja livremente interpretada de forma a atender aos clamores da sociedade, que busca muito mais a vingança privada do que propriamente a punição justa do agente. Tais premissas contrariam o modelo garantista, democrático e constitucionalizado de processo penal fundado nos fatos, não mais na pessoa. Ou seja, o que os defensores do lawfare defendem é um direito penal do autor ou direito penal do inimigo, contradizendo as proposições democrático-constitucionalizadas que preconizam pelo direito penal dos fatos, centrado na presunção da não culpabilidade (presunção de inocência), obrigatoriedade de fundamentação racional das decisões, contraditório, ampla defesa e devido processo legal.

Nesse sentido, a aplicabilidade do instituto do lawfare no direito brasileiro constitui uma afronta ao modelo garantista, democrático e constitucionalizado de processo penal, tendo em vista que compromete significativamente a formação participada do mérito processual. $\mathrm{O}$ modelo autocrático de processo penal reproduzido pelo instituto do lawfare coloca o acusado (inimigo do Estado) como coadjuvante do debate processual, em posição juridicamente de desigualdade, cerceia seu direito de defesa, atenta contra sua dignidade humana, presume sua culpabilidade, privilegia o protagonismo e discricionariedade judicial, além de legitimar a aplicabilidade de penas severas à pessoa do acusado, visto que os fatos que ensejaram a propositura da ação penal ficam relegados a segundo plano.

A releitura constitucionalizada do instituto do lawfare é de significativa importância para demonstrar que o mesmo representa uma afronta ao processo penal democrático, haja vista que torna inviável a formação participada do mérito processual, baseado em critérios trazidos pela racionalidade crítica. O processo constitucional democrático desconstrói o protagonismo judicial ao legitimar democraticamente o direito de os sujeitos do processo participarem dialeticamente da construção do provimento final. Deve-se assegurar aos sujeitos do processo iguais condições e oportunidades de construção da decisão final de mérito. Ademais, a racionalidade crítica passa a ser vista como o referencial que norteia o debate dos fatos alegados em juízo, devendo-se assegurar amplamente ao acusado o direito de defesa, o contraditório e não ser surpreendido com uma decisão distinta do que foi alegado, provado e debatido no âmbito processual. Contrariando todas essas premissas, o lawfare é um instituto que presume a culpabilidade do agente, categoriza pessoas como inimigo do Estado, fortalece o poder decisório do juiz, autoriza a utilização de critérios irracionais para decidir, além de tornar inviável a formação participada do mérito processual, tendo em vista que o acusado é o coadjuvante de um modelo de processo autocrático em que o magistrado é o protagonista.

\section{REFERÊNCIAS}

ANDRADE, Vera Regina Pereira de. A ilusão de Segurança Jurídica: do controle da violência à violência do controle penal. 1. ed. Porto Alegre: Livraria do Advogado Editora, 1997. 
ATALIBA, Geraldo. República e Constituição. São Paulo: Malheiros Editores, 2004.

BARACHO. José Alfredo de Oliveira. Processo Constitucional. Revista Forense, v. 337, Rio de Janeiro, jan./mar. 1997.

BARACHO, José Alfredo de Oliveira. Teoria geral do processo constitucional. Revista da Faculdade Mineira de Direito. v.2, ns. 3 e 4, p. 89-154. Belo Horizonte, $1^{\text {o e }} 2^{\circ}$ sem. 1999.

BRASIL. Portaria 666, de 25 de julho de 2019. Disponível em http://www.in.gov.br/en/web/dou/-/portaria-n-666-de-25-de-julho-de-2019-207244569. Acesso em 08 fev. 2020.

CARLSON, John; YEAOMANS, Neville. Whithergoeththelaw - humanityorbarbarity.

The Way Out - Radical Alternatives in Australia. Disponível em <http://www.laceweb.org.au/whi.htm>Acesso em: 12 fev. 2020

CASTILHO, Manoel Lauro Volkmer de. Direito Fundamental ao processo justi. O Caso Lula: a luta pela afirmação dos direitos fundamentais no Brasil. Coordenadores: Cristiano Zanin Martins, Valeska Teixeira Zanin Martins e Rafael Valim. São Paulo: Contracorrente, 2017.

CLARKE, Richard A. Contra Todos os Inimigos: Por dentro da guerra dos EUA contra o terror. São Paulo: Francis, 2004.

COSTA, Fabrício Veiga. A imparcialidade do juízo e a subjetividade do julgador. 2017. Disponível em: 〈http://www.iamg.org.br/lerpublicacao.php?publicacao=572>. Acesso em: 12 fev. 2020.

COSTA, Fabrício Veiga. MÉRITO PROCESSUAL: a formação participada nas ações coletivas. Belo Horizonte: Arraes, 2012.

DIAS, Ronaldo de Carvalho Bretas. Processo Constitucional e Estado Democrático de Direito. Belo Horizonte: Del Rey, 2010.

DUNLAP, Charles J. Law and Military Interventions: Preserving HumanitarianValues in $21{ }^{\text {st }}$ Conflicts. Disponível em <http://people.duke.edu/ pfeaver/dunlap.pdf > . Acesso em 14 fev. 2020.

DUNLAP, Charles J. Lawfare Today:a perspective. Yale journal of international affairs, Volume 3, Issue 1: Winter 2008.Disponívelem< http://yalejournal.org/wpcontent/uploads/2011/01/083111dunlap.pdf>Acessoem: 12 fev. 2020.

EAST TIMOR: thebuildingof a nation: an interview with Sergio Vieira de Mello. Europa Magazine of the European Affairs Society, Disponível em: <https://www.usp.br/svm/textos/ttimor-05.php>. Acesso em 7 jan. 2020

FAZZALARI, Elio. Instituzioni di diritto processuale. Padova: Cedam, 1992 
FERRAJOLI, Luigi. Direito e razão: teoria do garantismo penal. 4. ed. rev. São Paulo: Revista dos Tribunais, 2014.

GOMES, Luiz Flávio. A Dimensão da magistratura: No Estado constitucional e democrático de direito. São Paulo: Revista dos Tribunais, 1977.

GRESTA, Roberta Maia. Introdução aos Fundamentos da Processualidade Democrática. Coleção Estudos da Escola Mineira de Processo. v.1. Rio de Janeiro: Lumen Juris, 2014.

KITTRIE, Orde F. Lawfare: law as a weaponofwar. New York: Oxford University Press, 2016.

LAWFARE LOSES BIG. The Wall Street Journal.Disponível em:

<https://www.wsj.com/articles/SB10001424052970203718504577181191271527180> Acesso em: 13 fev. 2020.

LEAL, André Cordeiro. A instrumentalidade do processo em crise. Belo Horizonte: Mandamentos, 2008.

LEAL, Rosemiro Pereira. Teoria processual da decisão jurídica. São Paulo: Landy, 2002.

LEAL, Rosemiro Pereira. Teoria Geral do Processo. Primeiros Estudos. 8.ed. Rio de Janeiro: Forense, 2009.

LIANG, Quiao; XIANGSUI, Wang. Unrestrictedwarfare. Disponível em:<https://www.oodaloop.com/documents/unrestricted.pdf >. Acesso em 13 fev. 2020.

MELLO, Celso Antônio Bandeira de. Autonomia e Imparcialidade do Poder Judiciário. O Caso Lula: a luta pela afirmação dos direitos fundamentais no Brasil. Coordenadores: Cristiano Zanin Martins, Valeska Teixeira Zanin Martins e Rafael Valim. São Paulo: Contracorrente, 2017.

MENDES, Conrado Hübner. Direitos fundamentais, separação de poderes e deliberação. São Paulo: Saraiva, 2011.

PAOLINELLI, Camilla Mattos. O que é Processo Constitucional? . In: Âmbito Jurídico, Rio Grande, XIX, n. 149, jun 2016. Disponível em: <http://www.ambito-

juridico.com.br/site/index.php?n_link=revista_artigos_leitura\&artigo_id=17298\&revista_caderno =21>. Acesso em: 14 fev. 2020.

PAOLINELLI, Camilla Mattos. O ônus da prova no processo democrático. Coleção Estudos da Escola Mineira de Processo. v.3. Rio de Janeiro: Lumen Juris, 2014.

PENNA, Saulo Versiani. Controle e implementação processual de políticas públicas no Brasil. Belo Horizonte: Fórum, 2011.

VALIM, Rafael; COLANTUONO, Pablo Ángel Gutiérrez. O enfrentamento da corrupção nos limites do estado de direito. O Caso Lula: a luta pela afirmação dos direitos fundamentais no Brasil. Coordenadores: Cristiano Zanin Martins, Valeska Teixeira Zanin Martins e Rafael Valim. São Paulo: Contracorrente, 2017. 
ROCHA, Silvio Luis Ferreira da. A imparcialidade do Juiz. O Caso Lula: a luta pela afirmação dos direitos fundamentais no Brasil. Coordenadores: Cristiano Zanin Martins, Valeska Teixeira Zanin Martins e Rafael Valim. São Paulo: Contracorrente, 2017.

STRECK, Lenio Luiz. O QUE É ISTO - decido conforme minha consciência? 3.ed. Porto Alegre: Livraria do Advogado, 2012.

YAROCHEWSKY, Leonardo Isaac. Delação premiada como substituto da atividade investigativa do estado. O Caso Lula: a luta pela afirmação dos direitos fundamentais no Brasil. Coordenadores: Cristiano Zanin Martins, Valeska Teixeira Zanin Martins e Rafael Valim. São Paulo: Contracorrente, 2017.

YERYSHALMI, David; MUISE, Robert J. OffensiveanddefensiveLawfare: fightingcivilization jihad in america'scourts. Washington: Center fod Security Policy Press, 2015.

ZAFFARONI, Eugenio Raúl. El escándalo jurídico. 2016. Disponível em: https://www.pagina12.com.ar/diario/contratapa/13-313021-2016-10-30.html. Acesso em13 fev.2020. 